\title{
有機質肥料（なたね粕）が茶樹の生育，化学成分， 製茶品質および土㙵の化学性に及ほす影響
}

愛知県農業総合試験場畑地技術実験農場

西郷知博 - 渡辺訓司 - 森田昌愛* ・中野隆司

\section{Effect of Organic Fertilizer Application on the Growth of Tea Plant, Quality of Green Tea and Chemical Properties of Soils}

\author{
By Tomohiro Saigo, Kunji Watanabe, Masachika Morita \\ and Takashi NAKANo
}

Aichi Prefectual Agricultural Research Center

\section{1 まえがき}

窒素質肥料は，茶樹の生育，収量に最す効果がある が，製茶品質に対してもその影響は大きい。

このため，肥料試験のなかでは，従来より窒菜質肥料 に関する試験が数多く行われ，室菜質肥料の種類と生葉 収量；製茶品質との関係についてる試験成績加報告され ている。しかし，有機質肥料に関する試験成績としては， 宫崎県農試川南分場の詳細な報告があるが，報告の大部 分が生葉収量の多少，官能審查に上る品質の優劣にとど 亲り, 土境の化学性，茶葉の化学成分，さらに品質への 影響などについての報告は極めて少ない。また，多くの 有機䁲肥料のなかでななたね粕が他の有機質肥料に比べ て生葉収量，製茶品質に対してともに優れるとい5報告 すあり，今日でもなお，茶の品質向上になたね粕施用が 有効であるとする見解も持なれている。

製茶品質の要因は複雑であり，有機質肥料によって品
質が左右されるとは一概には決められず，多くの難解な 問題が残されている。そこで，これらの問題を解明する いとぐちをつくるため，まず有機質の窒素肥料としてな たね䊑，無機質の窒素肥料として硫安を共試し，有機啠 肥料（以下なたね粕とい5）と無機質肥料（以下硫安と いう）との施用比率をかえて 新植時より試験を始めた。

1971～1977年にわたり茶樹の生育，収量，製茶成分な らびに土塂の化学性などに及浔す影響について化学成分 の比較などを主体として検討したので，その結果を取り まとめて報告する。

\section{2 試”験 方 法}

2. 1 有機質肥料（なたね粕）の連用比較試験

表 1 K示す試験区別および 年度別施肥量により試験を 行った。肥料の分施率は表 2のとおりである。すなわち， 有機質肥料としてなた权粕を用い，年間窒素施用量の 20 \% (少量区)，60\%（多量区）をなたね粕で施用しだ。

表1 試験区別括よび年度別施肥量

\begin{tabular}{|c|c|c|c|c|}
\hline 処 & $\begin{array}{l}\text { 年閑窒素量に対す } \\
\text { る有機態素比率 }\end{array}$ & 成木園年閻 施 肥 量 & 年 度 ·別，施 & 肥 量 \\
\hline 有機質無施用 (硫 安 単 用) & $0^{\%}$ & $\mathrm{~N}: 65, \mathrm{P}_{2} \mathrm{O}_{5}: 30, \mathrm{~K}_{2} \mathrm{O}: 30^{\mathrm{kg}}$ & 1971 年 & $50^{\%}$ \\
\hline " 少量（なたね粕少量） & 20 & 同 & 1972 年 & 60 \\
\hline n多量（なたね粕多量） & 60 & 同 & 1973 年 & 70 \\
\hline \multirow{2}{*}{ 緩効性肥料. (C.D U 単体) } & 60 & 同 & 1974 年 & 80 \\
\hline & & & 1975年以後 & 100 \\
\hline
\end{tabular}

* 愛知県岡崎農業改良普及所

$\dagger$ 宮崎県農業試験場川南分場：農林省指定茶肥料試験成績，pp: 12 17 (1956). 


\begin{tabular}{|c|c|c|c|c|c|c|c|c|c|c|c|c|}
\hline \multirow{2}{*}{ 肥 料 の 種 類 } & \multicolumn{3}{|c|}{ 有機質無施用 } & \multicolumn{3}{|c|}{ 有機質少量 } & \multicolumn{3}{|c|}{ 有機質多量 } & \multicolumn{3}{|c|}{ 綬効 性 肥 料 } \\
\hline & 秋 肥 & 春 肥 & 夏肥 & 秋 肥 & 春 肥 & 夏肥 & 秋肥 & 春 肥 & 夏肥 & 秋 肥 & 春 肥 & 夏肥 \\
\hline \multirow{4}{*}{$\begin{array}{l}\text { なたね 粕 } \\
\text { 硫 } \\
\text { 熔成りん肥 } \\
\text { 過りん酸石灰 }\end{array}$} & & & & 120 & 120 & & 360 & 360 & & & & \\
\hline & 100 & 130 & 80 & 80 & 90 & 80 & 30 & 30 & 80 & 30 & 30 & 80 \\
\hline & 40 & 40 & & 35 & 35 & & 15 & 15 & & 35 & 35 & \\
\hline & 50 & 40 & & 35 & 35 & & 20 & 20 & & 50 & 50 & \\
\hline \multirow{2}{*}{$\begin{array}{l}\text { 塭 化 カ } \\
\mathrm{C} \text { D U 単 体 }\end{array}$} & 30 & 20 & & 25 & 20 & & 20 & 15 & & 30 & 20 & \\
\hline & & & & & & & & & & 60 & 56 & \\
\hline \multirow{2}{*}{$\begin{array}{l}\text { 咸 } \\
\text { 量 }\end{array}$} & 21.0 & 27.3 & 16.8 & 22.6 & 24.9 & 16.8 & 24.3 & 24.3 & 16.8 & 24.9 & 23.1 & 16.8 \\
\hline & 15.4 & 15.4 & & 15.4 & 15.4 & & 15.7 & 15.7 & & 15.1 & 15.1 & \\
\hline $\mathrm{K}_{2} \mathrm{O}$ & 18.0 & 12.0 & & 16.6 & 16.0 & & 16.7 & 13.7 & & 18.0 & $12 \cdot 0$ & \\
\hline
\end{tabular}

注） 1 . 秋肥は 9 月上旬, 春肥は 3 月上旬, 夏肥は 5 月中旬, 7 月上旬の 2 回とする。

2. 有機質無施用, 有機質少量の春肥は 3 月上旬の 2 回分施上する。

3. $\mathrm{CDU}$ 単体は $\mathrm{CDU} 31.0 \%$

なお，なたね粕多量区と有機質含量が同率（60\%）の緩 効性肥料区 (CDU 単体) を設け，さらに有機質無施用 区 (硫安単用) を対照区として比較検討を行った。なた ね粕および 楥效性肥料は秋肥と春肥に施用し，夏肥は全 区硫安のみとした。

1971 年 3 月 18 日《うね間 $1.8 \mathrm{~m}$ ，株關 $0.3 \mathrm{~m}$ の学条 植て定植したやぶきた 2 年生幼木園を供試し， 1 区 $22 \mathrm{~m}^{2}$ の3 連制で武験を行った。茶樹は定植 4 年目よりはさみ 摘みとした。供試任場には苦土石灰は施用せず，乙き草， しきわら，その他の有機物も投入しなかった。

生育調查は摘採時の芽長, 開葉数を, 収量構成要素は $20 \mathrm{~cm} \times 20 \mathrm{~cm}$ の枠摘みにより行った。

製茶は回分型製茶機（15 K 機）を用い，一番茶をせん 茶として製造し，品質を普通審査法（官能審査）により 審查した。ただし，1973 年度は少量製茶機 $(0.5 \mathrm{~K}$ 機) で製造し，品質の調查は行わなかった。

試験開始直前（1971 年3月）と 2 年後， 4 年後の秋肥 施用直前 (8月) と, 各区の土境を採取して化学性を比 較した。また，ほ場に批りる無機態空素の消長につい て，1977年春肥直前（3月 5 日）から一番茶摘採時（5 月6日）まで，深さ $0 〜 10 \mathrm{~cm}$ の土を採り無機態窒䒺と してアンモニア態窒素 $\left(\mathrm{NH}_{4}-\mathrm{N}\right)$ と硝酸態窒素 $\left(\mathrm{NO}_{3}-\right.$ N) の含量を測定した。同時に, 春肥直前と一番茶摘採 時の 2 回, 茶株の雨落ち部位, 深さ $0 \sim 20 \mathrm{~cm}$ にわたっ て分布する根を採取し, 細根 (径 $2 \mathrm{~mm}$ 以下) のアミ) 酸を調査した。さらに，1977 年一香茶摘採時における各 区の土跮 (梁さ $0 \sim 10 \mathrm{~cm}$ ) 拈上び一番茶化学成分含量 を調查した。

製茶の分析は茶の公定分析法, 遊離環元桾の定量は HANES の方法，カテキンの 分別定量はペーパークロマ トグラフによる切り取り抽出法，アミノ酸の定量は自動 分析法, 茶業打よび土壤の算機成分は原子吸光法, 無機
態窒素は CONWAY 微量拡散法でそれぞれ行った。

\section{2 無機化率補正試験}

なたね粕の無機化率は 60\%前後といわれ，硫安からの 窒素供給能に比べてかなり低いため，なたね粕を增量し て有機質無施用区（硫安区）と同等となるょ5にし，ほ 場における無機化率を経時的汇調査した。

試験設計は表 3 に示したように，有機質肥料としてな たね粕を用い，少量区と多量区を設け，それぞれに無機 化補正区（增量区）を設け，有機質無施用区(硫安単用) を対照区とした。肥料は $0 〜 15 \mathrm{~cm}$ の深さに施用して土 と混合した。1区面積 $1 \mathrm{~m}_{2} ， 1$ 区制とし，1975年 3 月 17 日から 5 月16日わたり試験を行った。

調查項目として試験期間中の全窒素含量と無機態室絭

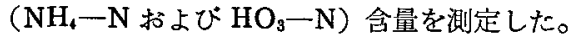

なお， 2.1，2.2はいずれも当場のほ場で行った。供試 湯の土壌断面調查結果は表 4 亿示すとおりで，洪積層 に由来する赤黄色土に古生層の崩積土が 混合した土㙲で ある。土性は粘土質で可そ性が強く，透水性が乏しいた

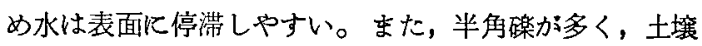
密度も高く農機具の摩耗が甚しい。供試任場は一般そさ い前作跡を1970年 12 月，ブルドーザーで深さ約 $60 \mathrm{~cm}$ まで耕起し，勾配 $1 / 100$ に造成した茶園である。

\section{3 試 験 結 果}

\section{1 有機質肥料の連用比較試験}

（1）茶芽の生育と収量

生育状況を 3 か年の平均值であらわし，表5に示した。

一番茶の開葉数は全般的に少なく，茅長はなたね粕多 量区，緩効性肥料区がよく伸び，なたね粕少量区がこれ に次ぎ，硫安区はやや劣った。样摘み結果からみた収量 構成要素は，芽数はなたね粕少量区が他区を上まわっ た。百芽重 (換算値) は緩効性肥料区，なたね粕多量区 
表 3 補 正 試 験 区 構 成

\begin{tabular}{|c|c|c|c|c|c|}
\hline \multirow{2}{*}{ 処 } & \multirow{2}{*}{ 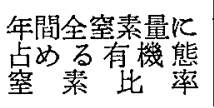 } & \multicolumn{2}{|c|}{ 本試験における } & \multicolumn{2}{|c|}{$1 \mathrm{~m}^{2}$ 当り } \\
\hline & & 有機態穻素比率 & 全窒素量 & 試 & 肥 \\
\hline 1 区: 有 機 (硫安舞用) $^{\text {施 }}$ 用 & $0 \%$ & $0 \%$ & $39.9^{g}$ & 硫 & $190^{\mathrm{g}}$ \\
\hline 2 区: 有 機(補姃なし） 少 & 20 & 32.5 & 34.7 & 硫なね案 & $\frac{128}{260}$ \\
\hline 3 区: 有機質少量 - 補正 & 20 & 44.7 & 39.9 & 硫たね安 & $\frac{128}{434}$ \\
\hline 4 区: 有 機(補正なし) & 60 & 97.5 & 24.2 & 硫たね安 & $\begin{array}{c}4 \\
780 \\
\end{array}$ \\
\hline 5 区：有機質多量 - 補 正 & 60 & 99.9 & 39.8 & 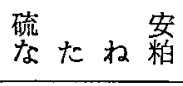 & $\begin{array}{r}4 \\
1300 \\
\end{array}$ \\
\hline
\end{tabular}

注）1。窒䒺施用量は表 1 ，春肥の 50\%增とした。

2. 窑素の無機化率を硫安 $100 \%$ ，なたね粕 $60 \%$ と仮定した。

表 4 供試䚾場 の土裹断面調查結果

\begin{tabular}{|c|c|c|c|c|c|c|c|c|c|c|c|c|c|c|}
\hline 層 & 位 & $\begin{array}{l}\text { 去層の } \\
\end{array}$ & 土 色 & 腐植 & 斑紋 & 土性 & 磞 & 構造 & 孔げき & ち密度 & 可そ性 & 粘着怕 & 透水性 & 湿り \\
\hline I & 層 & $\begin{array}{c}\text { cm } \\
0 \sim 42\end{array}$ & 7.5 YR $6 / 8$ & $\mathrm{H}_{1}$ & なし & $\mathrm{LiC}$ & $\begin{array}{c}\text { 半角 } \\
\mathrm{ka}_{3} \mathrm{~kb}_{1}\end{array}$ & $\mathrm{BL}_{2}$ & $\mathrm{CHa}_{2}$ & 17.6 & 強 & ·強 & 中 & $\mathrm{W}_{3}$ \\
\hline II & 層 & $42 \sim$ & $10 \mathrm{YR} 8 / 8$ & $\mathrm{H}_{1}$ & なし & $\mathrm{HC}$ & $\begin{array}{c}\text { 半角 } \\
\mathrm{Ka}_{8} \mathrm{~Kb}_{1}\end{array}$ & $\mathrm{BL}_{2}$ & $\mathrm{CHa}_{1}$ & 20.5 & 強 & 強 & 小 & $W_{3}$ \\
\hline
\end{tabular}

注） 1. I層とII層の境付近より水がにじみ出る。

2. 地質……洪皘層に固結水成岩の崩樻が影響している。

3. 有効土層……1 $\mathrm{m}$ 以上

表 5 茶芽の生育収量（1973～1975年，3力年平均）

\begin{tabular}{|c|c|c|c|c|c|c|c|c|c|}
\hline \multirow[b]{2}{*}{ 処 } & \multirow{2}{*}{ 茶 } & \multirow{2}{*}{ 芽 長 } & \multirow{2}{*}{ 開葉数 } & \multicolumn{4}{|c|}{$20 \mathrm{~cm} \times 20 \mathrm{~cm}$ 枠摘み } & \multicolumn{2}{|c|}{ 収量 } \\
\hline & & & & 芽 数 & 芽 & 百芽重 & 出開度 & 10a 換算 & 数 \\
\hline 有機質無施用 & $\begin{array}{l}\text { 一蕃茶 } \\
\text { 二 } "\end{array}$ & $\begin{array}{l}\mathbf{c m} \\
8.1 \\
8.7\end{array}$ & $\begin{array}{l}3.8^{\text {枚 }} \\
4.5\end{array}$ & $\begin{array}{l}47.5^{\text {芽 }} \\
53.4\end{array}$ & $27.6^{\mathrm{g}}$ & $\begin{array}{l}62.7^{\mathrm{g}} \\
87.0\end{array}$ & $\begin{array}{l}68.3^{\% 6} \\
88.5\end{array}$ & $\begin{array}{l}\mathrm{kg} \\
328.0^{\mathrm{k}} \\
343.3\end{array}$ & $\begin{array}{l}100 \\
100\end{array}$ \\
\hline 有機質少量 & $\begin{array}{l}\text { - } " ~ \\
\text { 三 } "\end{array}$ & $\begin{array}{l}8.2 \\
9.9\end{array}$ & $\begin{array}{l}3.9 \\
4.6\end{array}$ & $\begin{array}{l}52.3 \\
52.8\end{array}$ & $\begin{array}{l}28.8 \\
37.3\end{array}$ & $\begin{array}{l}57.5 \\
78.9\end{array}$ & $\begin{array}{l}63.6 \\
89.1\end{array}$ & $\begin{array}{l}324.1 \\
316.6\end{array}$ & $\begin{array}{l}98.8 \\
92.2\end{array}$ \\
\hline 有機需多量 & $\begin{array}{l}=n \\
=n\end{array}$ & $\begin{array}{l}8.8 \\
8.7\end{array}$ & $\begin{array}{l}3.9 \\
4.3\end{array}$ & $\begin{array}{l}48.0 \\
53.0\end{array}$ & $\begin{array}{l}30.3 \\
39.1\end{array}$ & $\begin{array}{l}67.0 \\
83.2\end{array}$ & $\begin{array}{l}66.2 \\
89.9\end{array}$ & $\begin{array}{l}323.1 \\
327.5\end{array}$ & $\begin{array}{l}98.5 \\
95.4\end{array}$ \\
\hline 楥効 性 肥 料 & $\begin{array}{l}\overrightarrow{7} \\
=\end{array}$ & $\begin{array}{l}8.4 \\
8.7\end{array}$ & $\begin{array}{l}3.8 \\
4.4\end{array}$ & $\begin{array}{l}48.3 \\
48.0\end{array}$ & $\begin{array}{l}30.8 \\
37.5\end{array}$ & $\begin{array}{l}66.7 \\
85.8\end{array}$ & $\begin{array}{l}72.6 \\
93.2\end{array}$ & $\begin{array}{l}322.8 \\
326.8\end{array}$ & $\begin{array}{l}98.4 \\
95.2 \\
\end{array}$ \\
\hline
\end{tabular}

が重く，芽数の多いなたね粕少量区は最も軽かった。区 別には，なたね粕多量区と緩効性肥料区は芽数は少ない が芽の生育速度が早いので百芽重が重い。なたね粕少量 区は芽数は多いが，芽が小さいので芽重す小さい。硫安 区はなたね粕少量区と同様汇芽は小さいが，出開度が進 み百芽重は比較的重いなど，扮括よそ以上の傾向を示し たが収量の区間差は僅かであった。

二番茶はなたね粕少量区の芽の生育がすぐれたが，そ の他の区に掂ける芽長; “開葉数には大きな差異はみられ
なかった。収量構成要素では, 硫安区は芽数が多くて百 芽重も重かったが，なたね粕少量区はやや軽く，なたね 粕多量区，緩効性肥料区ては芽数が少ない㑯向为みられ た。収量には区間差がみられ，芽数が多く芽重も重い硫 安区が最も多く，次いでなたね粕多量区，緩効性肥料区 の順となり，芽重が軽いなたね粕少量区は最す劣った。

（2）製 茶品質

品質を官能審査により比較して表6に示した。 これらの結果，なたね粕施用の影響がみられ，総合評 
表6 製 茶品質 (世九荼, 一番茶)

\begin{tabular}{|c|c|c|c|c|c|c|c|c|c|}
\hline 処 & 理 & 年 度 & 形 状 & 色 沢 & 水 色 & 香 気 & 味 & 総合計 & 順 位 \\
\hline \multirow{2}{*}{ 有 機 質 無 } & \multirow{2}{*}{ 施 用 } & 1974 & 17 & 17 & 18 & 18.5 & 18.5 & 89 & 4 \\
\hline & & 1975 & 20 & 20 & 18.5 & 17 & 18 & 93.5 & 4 \\
\hline & \multirow{2}{*}{ 少 } & 1974 & 20 & 20 & 19 & 19 & 19 & 97 & 2 \\
\hline 有 機 質 & & 1975 & 18.5 & 19 & 20 & 19 & 19 & 95.5 & 2 \\
\hline & \multirow[b]{2}{*}{ 量 } & 1974 & 19 & 19 & 20 & 19.5 & 20 & 97.5 & 1 \\
\hline 有 機 質 & & 1975 & 19.5 & 18 & 19.5 & 20 & 20 & 98 & 1 \\
\hline \multirow{2}{*}{\multicolumn{2}{|c|}{ 湲 効 性 肥 料 }} & 1974 & 18 & 18.5 & 17 & 20 & 17 & 90.5 & 3 \\
\hline & & 1975 & 19 & 19.5 & 19 & 18.5 & 19 & 95 & 3 \\
\hline
\end{tabular}

点と内質では区間差が顕著であった。しかし，外観では 年度に上る変動のため明らかではなかった。すなわら， 内質では，水色，香気，味とるになた机粕を施用した両 区が覔れた。なたね粕多量区の水色は清澄な黄金色であ り，味は濃くはないが，すっきりしたうま味が感じられ た。緩効性肥料区はなた称粕施用の両区に比べて水色， 味がやや劣ったが，香気は僅か比優れた。総合評点で は，なたね粕多量区>なたね粕少量区>緩効性肥料区> 硫安区の順となり，なだ粕多量区と硫安区の差は大き かった。

（3）製茶成 分

熱晹可溶分, 全窒菜, タンニン, 可溶性窒素, アミ， 酸などを分析し，表 $7 ， 8 ， 9$ とそれぞれ示した。
タンニン，可溶性窒素含量拈よびカフェインについて はなたね粕施用による 差異に一定の傾问はみられなかっ た。全空菜含量は硫安区が多く，なたね粕少量区>緩効 性肥料区の順で，なたね粕多量区は少なかったか，指数 でるとその差は少ないといえる。熱湯可溶分はなたね 粕施用により增加する傾向がみられた。遊離還元桾はな たね粕施用区亿多く，緩効性肥料区，硫安区に少なかっ た。全アミノ酸量は硫安区が多く，次いで緩効性肥料 区，なたね粕少量区となり，なたね粕多量区は最る少な かった。

各種了ミノ酸の含量比率は，テアニンが $60 \%$ 前後を占 めて最も多く，次いでグルタミン酸，セリンが $10 \%$ 台， アスパラギン酸，アルギニンその他は 10\%以下となって

表 7 製 茶 成 分 (一番 茶)

\begin{tabular}{|c|c|c|c|c|c|c|c|}
\hline 理 & 年 度 & 熱溶燙 & 全窒素 & タンニン & $\begin{array}{l}\text { 可溶性 } \\
\text { 絮 }\end{array}$ & $\begin{array}{l}\text { カ } \\
1\end{array}$ & 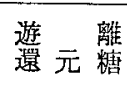 \\
\hline \multirow{4}{*}{ 有機質無施用 } & \multirow{3}{*}{$\begin{array}{l}1973 \\
1974 \\
1975\end{array}$} & 38.6 & 5.67 & 11.7 & - & 2.68 & 1.83 \\
\hline & & 36.2 & 5.29 & 10.1 & 1.72 & - & - \\
\hline & & 37.6 & 5.04 & 10.8 & 1.57 & - & - \\
\hline & 平 均 & 37.5 & 5.33 & 10.9 & 1.65 & 2.68 & 1.83 \\
\hline \multirow{4}{*}{ 有機質少量 } & \multirow{3}{*}{$\begin{array}{l}1973 \\
1974 \\
1975\end{array}$} & 40.0 & 5.64 & 12.3 & - & 2.68 & 2.11 \\
\hline & & 37.9 & 5.17 & 9.6 & 1.71 & - & - \\
\hline & & 37.6 & 5.01 & 10.2 & 1.59 & - & - \\
\hline & 平 均 & 38.5 & 5.27 & 10.7 & 1.65 & 2.68 & 2.11 \\
\hline \multirow{4}{*}{ 有機質，多量 } & \multirow{3}{*}{$\begin{array}{l}1973 \\
1974 \\
1975\end{array}$} & 40.8 & 5.51 & 12.1 & 一 & 2.36 & 1.98 \\
\hline & & 37.6 & 4.98 & 10.5 & 1.78 & - & 一 \\
\hline & & 37.4 & 4.94 & 10.5 & 1.51 & - & - \\
\hline & 平 均 & 38.6 & 5.14 & 11.0 & 1.65 & 2.36 & 1.98 \\
\hline \multirow{4}{*}{ 綬 効 性 肥 料 } & \multirow{3}{*}{$\begin{array}{l}1973 \\
1974 \\
1975\end{array}$} & 39.8 & 5.61 & 12.0 & - & 2.54 & 1.89 \\
\hline & & $37: 0$ & 4.97 & 10.9 & 1.72 & - & - \\
\hline & & 36.8 & 4.88 & 10.3 & 1.58 & - & - \\
\hline & 平均 & 37.9 & 5.15 & 11.1 & 1.64 & 2.54 & 1.89 \\
\hline
\end{tabular}


表 8 製茶中のアミノ酸含量 (一蕃茶) 比率

\begin{tabular}{|c|c|c|c|c|c|c|c|c|}
\hline 理 & 年 度 & テアニン & セリン & $\begin{array}{l}\text { グル 多 } \\
\text { 酸 }\end{array}$ & $\begin{array}{l}\text { アスス゚ラ } \\
\text { ギン酸 }\end{array}$ & $\begin{array}{l}\Im \\
=\end{array}$ & その他 & 全アミノ酸量 \\
\hline \multirow{3}{*}{ 有 機 質 無 施 用 } & 1973 & $51.2^{\%}$ & $13.1^{\%}$ & $14.8^{96}$ & $8.6^{\%}$ & $5.1^{\%}$ & $7.2^{\% 6}$ & $\begin{array}{l}\mathrm{mg} / 100 \mathrm{~g} \\
2301.8\end{array}$ \\
\hline & 1974 & 55.6 & 14.4 & 10.5 & 7.1 & 6.8 & 5.6 & 3093.3 \\
\hline & 平 均 & 53.4 & 13.8 & 12.7 & 7.9 & 6.0 & 6.4 & 2697.6 \\
\hline \multirow{3}{*}{ 有 機質 少 量 } & 1973 & 58.8 & 8.0 & 14.6 & 6.2 & .4 .2 & 8.2 & 1876.5 \\
\hline & 1974 & 56.2 & 14.3 & 9.4 & 7.1 & 7.0 & 6.0 & 3147.6 \\
\hline & 平 均 & 57.5 & 11.2 & 12.0 & 6.7 & 5.6 & 7.1 & 2512.1 \\
\hline \multirow{3}{*}{ 有機質多 量 } & 1973 & 63.4 & 6.1 & 13.5 & 5.7 & 3.1 & 8.2 & 2226.4 \\
\hline & 1974 & 58.9 & 13.0 & 9.1 & 6.3 & 6.7 & 6.0 & 2532.2 \\
\hline & 平 均 & 61.2 & 9.6 & 11.3 & 6.0 & 4.9 & 7.1 & 2379.3 \\
\hline \multirow{3}{*}{ 暧 効 性 肥 料 } & 1973 & 58.3 & 9.2 & 12.5 & 10.2 & 3.3 & 6.5 & 2590.9 \\
\hline & 1974 & 59.4 & 12.0 & 9.4 & 7.3 & 4.5 & 7.4 & 2671.4 \\
\hline & 平均 & 58.9 & 10.6 & 11.0 & 8.8 & 3.9 & 7.0 & 2631.2 \\
\hline
\end{tabular}

表9製茶中の力テキン（1973年）

(\%)

\begin{tabular}{|c|c|c|c|c|c|c|c|c|}
\hline 処 & 茶 期 & 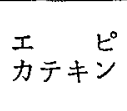 & $\begin{array}{l}\text { エピガロ } \\
\text { カテキン }\end{array}$ & 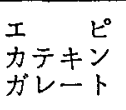 & $\begin{array}{l}\text { エピガロ } \\
\text { カテテキン } \\
\text { ガレート }\end{array}$ & 遊離 型 & $\begin{array}{l}\text { エステル } \\
\text { カ型 } \\
\text { カテン }\end{array}$ & 合計値 \\
\hline \multirow{2}{*}{ 有機質無施用 } & 一番茶 & 1.10 & 3.59 & 1.40 & 5.13 & 4.69 & 6.53 & 11.22 \\
\hline & $="$ & 1.18 & 4.95 & 1.37 & 6.17 & 6.13 & 7.54 & 13.67 \\
\hline \multirow{2}{*}{ 有機質少量 } & - " & 1.29 & 3.72 & 1.16 & 5.23 & 5.01 & 6.39 & 11.40 \\
\hline & 二 " & 1.20 & 4.74 & 1.06 & 5.77 & 5.94 & 6.83 & 12.77 \\
\hline \multirow{2}{*}{ 有 機 質 多 量 } & - " & 1.14 & 3.93 & 1.38 & 5.29 & 5.07 & 6.67 & 11.74 \\
\hline & $=" \prime$ & 1.12 & 4.90 & 1.34 & 6.29 & 6.02 & 7.63 & 13.65 \\
\hline \multirow{2}{*}{ 緩 効 性 肥 料 } & - " & 1.18 & 3.79 & 1.36 & 5.25 & 4.97 & 6.61 & 11.58 \\
\hline & $=n$ & 1.09 & 4.84 & 1.13 & 5.85 & 5.93 & 6.98 & 12.91 \\
\hline
\end{tabular}

いる。アミノ酸のなかで茶の5ま味成分の主体とされる テアニンは，なたね粕施用によって含量比率が高まる傾 向がみられ，なたね粕多量区>緩効性肥料区>ななね粕 少量区>硫安区の順となり，なたね粕多量施用区は無施 用区（硫安区）に比へて約 8\%の差がみられた。グルタ ミン酸拉よびアスパラギン酸の含量は数値が低いるの の，硫安区〉なたね粕少罬区〉なたね粕多量区の順とな り，テアニンの場合々は異なる傾问を示した。縟勃性肥 料区はアスパラギン酸が他区よりやや多い傾向を示し た。また，なたね粕区と硫安区について，テアニンの含 量比率と製茶品質との相関をみたところ，総合評点で 0.679, 内質では 0.959**（1％帐率で有意）であり， 内質に対して高い相関がみられた。

一番茶のカテキン含量はなたね粕施用の雨区でやや多
く，緩効性肥料区と硫安区では少ないが，その差は小さ かった。また，カテキン化占める遊離型カテキン比率は なたね粕施用の両区に多かった。二番茶では処理区間の 差は明らかでかった。

(4) 土境の化学性

土境の化学性を表 10 に示した。

$\mathrm{pH}\left(\mathrm{H}_{2} \mathrm{O}\right)$ は全般的に 2 年後， 4 年後と年次を追って 低下する傾向がみられた。しかし，なたね粕施用による 影篈は明らかではなかった。土境の深さ別では上層が下 層に比べて低下の 程度が大きく，4年後には各区とる $\mathrm{pH}$ 值として 1 以上の低下が みられた。固換酸度 $\left(\mathrm{Y}_{1}\right)$ は各区とす增加したが，上層では硫安区の場合がやや低 くなたね粕施用区では高い傾向がみられた。下首は变 動が多いが，一定の傾向はみられなかった。 
表10 土壤化学性

\begin{tabular}{|c|c|c|c|c|c|c|c|c|c|c|c|}
\hline \multirow{2}{*}{ 処 } & \multirow{2}{*}{$\begin{array}{l}\text { 採土の } \\
\text { 深 }\end{array}$} & \multirow{2}{*}{ 採 圭 } & \multicolumn{2}{|c|}{$\mathrm{pH}$} & \multirow{2}{*}{$Y_{1}$} & \multirow{2}{*}{ CEC } & \multicolumn{2}{|c|}{ 置換性塩基 } & \multirow{2}{*}{$\begin{array}{l}\text { 有効態 } \\
\text { リン酸 }\end{array}$} & \multirow{2}{*}{ 全炭素 } & \multirow{2}{*}{ 全窒菜 } \\
\hline & & & $\mathrm{H}_{2} \mathrm{O}$ & $\mathrm{KCl}$ & & & $\mathrm{CaO}$ & $\mathrm{MgO}$ & & & \\
\hline \multirow{2}{*}{ 有機質無施用 } & $\begin{array}{r}\mathrm{cn} \\
0 \sim 15\end{array}$ & $\begin{array}{l}\text { 開始前 } \\
2 \text { 年後 } \\
4 \text { " }\end{array}$ & $\begin{array}{l}5.7 \\
4.5 \\
4.5\end{array}$ & $\begin{array}{l}- \\
3.4 \\
3.9\end{array}$ & $\begin{array}{r}1.8 \\
14.4 \\
13.0\end{array}$ & $\begin{array}{r}8.4 \\
- \\
10.7\end{array}$ & $\begin{array}{r}\mathrm{mg} / 100 \mathrm{~g} \\
127.6 \\
63.1 \\
111.1\end{array}$ & $\begin{array}{c}\mathrm{mg} / 100 \mathrm{~g} \\
19.8 \\
13.9 \\
19.9\end{array}$ & $\begin{array}{c}\mathrm{mg} / 100 \mathrm{~g} \\
15.5 \\
16.0 \\
54.0\end{array}$ & $\begin{array}{l}0.71 \\
0.77 \\
0.95\end{array}$ & $\begin{array}{l}0.08 \\
0.13 \\
0.12\end{array}$ \\
\hline & $15 \sim 30$ & $\begin{array}{l}\text { 開始前 } \\
2 \text { 年後 } \\
4 " \prime\end{array}$ & $\begin{array}{l}5.7 \\
4.9 \\
4.5 \\
\end{array}$ & $\begin{array}{l}-\overline{3.7} \\
3.8\end{array}$ & $\begin{array}{r}1.8 \\
7.0 \\
20.4 \\
\end{array}$ & $\begin{array}{r}8.4 \\
- \\
8.9\end{array}$ & $\begin{array}{r}127.6 \\
88.7 \\
54.3 \\
\end{array}$ & $\begin{array}{l}19.8 \\
14.4 \\
23.4\end{array}$ & $\begin{array}{r}15.5 \\
7.5 \\
29.5\end{array}$ & $\begin{array}{l}0.71 \\
0.49 \\
0.52\end{array}$ & $\begin{array}{l}0.08 \\
0.10 \\
0.08\end{array}$ \\
\hline \multirow{2}{*}{ 有機質少量 } & $0 \sim 15$ & \begin{tabular}{|c|} 
開始前 \\
2 年後 \\
$4 "$ "
\end{tabular} & $\begin{array}{l}5.7 \\
5.0 \\
4.4\end{array}$ & $\begin{array}{l}- \\
3.6 \\
3.6\end{array}$ & $\begin{array}{r}1.8 \\
13.8 \\
16.8\end{array}$ & $\begin{array}{r}8.4 \\
-\overrightarrow{11.1}\end{array}$ & $\begin{array}{r}127.6 \\
72.2 \\
80.7\end{array}$ & $\begin{array}{l}19.8 \\
12.6 \\
27.5\end{array}$ & $\begin{array}{l}15.5 \\
12.4 \\
57.1\end{array}$ & $\begin{array}{l}0.71 \\
0.66 \\
1.14\end{array}$ & $\begin{array}{l}0.08 \\
0.11 \\
0.10\end{array}$ \\
\hline & $15 \sim 30$ & \begin{tabular}{l} 
開始前 \\
2 年後 \\
$4 ＂ ｝$ & $\begin{array}{l}5.7 \\
5.2 \\
5.1\end{array}$ & $\begin{array}{l}-\overline{4} \\
4.1 \\
4.1\end{array}$ & $\begin{array}{l}1.8 \\
2.5 \\
8.7\end{array}$ & $\begin{array}{r}8.4 \\
-\overrightarrow{10.0}\end{array}$ & $\begin{array}{l}127.6 \\
126.2 \\
106.2\end{array}$ & $\begin{array}{l}19.8 \\
28.5 \\
38.6\end{array}$ & $\begin{array}{r}15.5 \\
9.6 \\
28.0\end{array}$ & $\begin{array}{l}0.71 \\
0.57 \\
0.71\end{array}$ & $\begin{array}{l}0.08 \\
0.10 \\
0.08\end{array}$ \\
\hline \multirow{2}{*}{ 有機質多量 } & $0 \sim 15$ & $\begin{array}{c}\text { 開始前 } \\
2 \text { 年後 } \\
4 "\end{array}$ & $\begin{array}{l}5.7 \\
4.9 \\
4.4\end{array}$ & $\begin{array}{l}-\overline{2} \\
4.2 \\
3.7\end{array}$ & $\begin{array}{r}1.8 \\
11.3 \\
20.0\end{array}$ & $\begin{array}{r}8.4 \\
- \\
10.7\end{array}$ & $\begin{array}{r}127.6 \\
94.5 \\
68.7\end{array}$ & $\begin{array}{l}19.8 \\
21.5 \\
33.5\end{array}$ & $\begin{array}{r}15.5 \\
9.3 \\
41.4\end{array}$ & $\begin{array}{l}0.71 \\
0.79 \\
1.12\end{array}$ & $\begin{array}{l}0.08 \\
0.15 \\
0.13\end{array}$ \\
\hline & $15 \sim 30$ & $\begin{array}{c}\text { 開始前 } \\
2 \text { 年後 } \\
4 n " ~\end{array}$ & $\begin{array}{l}5.7 \\
5.2 \\
4.4\end{array}$ & $\begin{array}{l}- \\
4.1 \\
3.7\end{array}$ & $\begin{array}{r}1.8 \\
2.5 \\
29.3\end{array}$ & $\begin{array}{c}8.4 \\
- \\
8.8\end{array}$ & $\begin{array}{r}127.6 \\
126.2 \\
40.0\end{array}$ & $\begin{array}{l}19.8 \\
28.5 \\
28.5\end{array}$ & $\begin{array}{r}15.5 \\
9.6 \\
26.3\end{array}$ & $\begin{array}{l}0.71 \\
0.57 \\
0.54\end{array}$ & $\begin{array}{l}0.08 \\
0.10 \\
0.07\end{array}$ \\
\hline \multirow{2}{*}{ 緩勃 性 肥 料 } & $0 \sim 15$ & \begin{tabular}{|c|c|} 
開始前 \\
2 年後 \\
4 "
\end{tabular} & $\begin{array}{l}5.7 \\
4.9 \\
4.1\end{array}$ & $\begin{array}{l}- \\
4.2 \\
3.6\end{array}$ & $\begin{array}{r}1.8 \\
11.3 \\
26.5\end{array}$ & $\begin{array}{c}8.4 \\
- \\
8.9\end{array}$ & $\begin{array}{r}127.6 \\
94.7 \\
22.4\end{array}$ & $\begin{array}{l}19.8 \\
21.5 \\
18.9\end{array}$ & $\begin{array}{r}15.5 \\
9.3 \\
29.5\end{array}$ & $\begin{array}{l}0.71 \\
0.79 \\
0.89\end{array}$ & $\begin{array}{l}0.08 \\
0.15 \\
0.11\end{array}$ \\
\hline & $15 \sim 30$ & $\begin{array}{c}\text { 開始前 } \\
2 \text { 年後 } \\
4 n\end{array}$ & $\begin{array}{l}5.7 \\
5.1 \\
4.4\end{array}$ & $\begin{array}{l}- \\
3.9 \\
3.8\end{array}$ & $\begin{array}{r}1.8 \\
3.4 \\
25.2\end{array}$ & $\begin{array}{c}8.4 \\
- \\
8.1\end{array}$ & $\begin{array}{r}127.6 \\
101.7 \\
32.6\end{array}$ & $\begin{array}{l}19.8 \\
22.7 \\
23.7\end{array}$ & $\begin{array}{r}15.5 \\
5.7 \\
26.5\end{array}$ & $\begin{array}{l}0.71 \\
0.45 \\
0.41\end{array}$ & $\begin{array}{l}0.08 \\
0.08 \\
0.05\end{array}$ \\
\hline
\end{tabular}
\end{tabular}

塩基置換容量 (CEC) は上層に变化がみられ，各区之 る增加したが，なたね粕，縟効性肥料などの施用による 影響は明らかではなかった。

全炭素は各区とも上層では增加したが，なたね粕施用 の両区のほうが，湲效性肥料区および硫安区に比べて增 加量が多かった。下層では影響は少なく一定の傾向がみ られなかった。全掌素は各区とも上層において增加がみ られたが，処理による影響は明らかではなく，下首での 変化は少なかった。

石灭飽和度は試験期間中，石灰を施用していないため 各区とす低下したが，緩效性肥料区の場合が最す低かっ た有勃態 リン酸は試験開始前に比べていずれの区も上 層，下層ともに増加した。すなわち，上層では 4 年後に は大幅僧加したが，下读では区間差は少なく洪皘層赤 黄色土の適正値（30４0mg/100g）飞近い値を示してい た。

以上，なたね粕施用により 全炭素の增加抢よび塩基置 換容量の増大傾向が誌められたが, $\mathrm{pH}$ ，全社素，置換性 塩基ならびに石灰飽和度については明らかな差はみられ
なかった。緩効性肥料区は他の3区に比べ塩基置換容量 がやや小さく，有効態リン酸，全炭素，全坴素含量す少 ない順向であった。

\section{（5）注場に打ける無機態窒素の変動}

土壤中の無機態窑菜含量の変動を図 1 K示し，その5 ち $\mathrm{NH}_{4}-\mathrm{N}$ と $\mathrm{NO}_{3}-\mathrm{N}$ の比率を表11に示した。

春肥直前の無機態窒素は 1〜 $5 \mathrm{mg} / 100 \mathrm{~g}$ 程度にすぎ なかったが，春肥施用によって増加し，なかでも硫安区 が他区に比べて著しく多かった。また，処理による差に ついてみると，硫安区では施用 10日後に急増したが，そ の後活淄直線的に減少し，芽出肥の施用により再度堌加 をみたが，60日後の摘採時には再び低下した。なたね粕 多量区は 10 日後，20日後と日を追って增加し，40日後 には最高を示したが，硫安区に比べると少なかった。な たね粕少量区は硫安区とよく似た動を示したが，10日 後 20 日後の含量は硫安区に比べて少なかった。楥効性 肥料区は終始，無機態窒素含量が少なく，最高になった

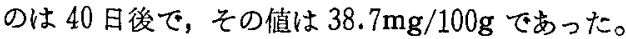

無機態窒素のうち, $\mathrm{NH}_{4}-\mathrm{N}$ と $\mathrm{NO}_{8}-\mathrm{N}$ の動きをみ 


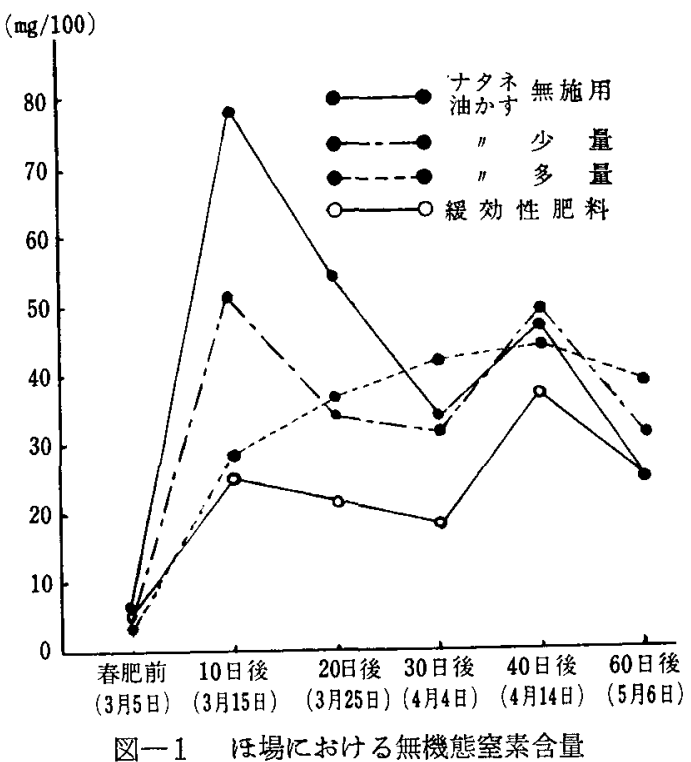

ると，各区とす20日後すでは $\mathrm{NH}_{4}-\mathrm{N}$ の比率が高く， $95 \%$ 前後を示し， 30 日後になると減少し始め，60日後 ではさらに低下して約 60〜80\%となり， $\mathrm{NO}_{3}-\mathrm{N}$ の比 率が高去った。60日後汇括ける $\mathrm{NH}_{4}$ 一N の比率は硫安 区が低く，緩効性肥料区がやや高く，なたね粕施用の両 区は活涩中間であった。

\section{（6）茶樹細根のアミノ酸}

細根のアミノ酸含量を表12k示した。

春肥直前の細根の全アミノ酸量は縟勃性肥料区と硫安 区に多く，なたね粕施用の両区はとるに少なく，前2 者 の約 $80 \%$ \%っった。春肥施用約 2 力月後, 一番茶摘採 時の全アミノ酸量は各区とす增加し，なかです硫安区の 增加が大きかった。試験区別にみると，硫安区，緩効性 肥料区の全アミノ酸量が多く、なたね粕施用の両区はと すに前 2 者の約 $70 \%$ で少なく，春肥直前とよく似た傾向 を示し，なたね粕施用による全アミノ酸量への影響がみ られた。春肥施用後の細根のアミノ酸含量についてみる

表11 ほ場に打ける無機態窒素の変動

$\left(\mathrm{NH}_{4}-\mathrm{H}<\mathrm{NO}_{3}-\mathrm{N}\right.$ の 比率)

\begin{tabular}{|c|c|c|c|c|c|c|c|}
\hline 処 & 窒素の形態 & $\begin{array}{l}\text { 春萌 前 } \\
3 \text { 月 }\end{array}$ & 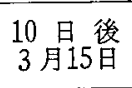 & $\begin{array}{l}20 \text { 日摞 } \\
3 \text { 月 } 25 \text { 日 }\end{array}$ & $\begin{array}{c}30 \text { 日 後 } \\
4 \text { 月 } 4 \text { 日 }\end{array}$ & $\begin{array}{l}40 \text { 星摞 } \\
4 \text { 月14等 }\end{array}$ & $\begin{array}{l}60 \text { 日 後 } \\
5 \text { 月 } 6 \text { 列 }\end{array}$ \\
\hline \multirow[b]{2}{*}{ 有機質無施用 } & $\mathrm{NH}_{4}-\mathrm{N}$ & 0 & 95.6 & 96.1 & 83.2 & 91.3 & 63.2 \\
\hline & $\mathrm{NO}_{3}-\mathrm{N}$ & 100 & 4.4 & 3.9 & 16.8 & 8.7 & 36.8 \\
\hline \multirow{2}{*}{ 有機岳少量 } & $\overline{\mathrm{NH}_{4}-\mathrm{N}}$ & 90.7 & 94.5 & 94.8 & 89.2 & 85.4 & 72.2 \\
\hline & $\mathrm{NO}_{3}-\mathrm{N}$ & 9.3 & 5.5 & 5.2 & 10.8 & 14.6 & 27.8 \\
\hline \multirow{2}{*}{ 有機筫多量 } & $\mathrm{NH}_{4}-\mathrm{N}$ & 52.6 & 71.9 & 94.7 & 90.5 & 74.2 & 68.1 \\
\hline & $\mathrm{NO}_{3}-\mathrm{N}$ & 47.4 & 28.1 & 5.3 & 9.5 & 25.8 & 31.9 \\
\hline \multirow{2}{*}{ 緩効性肥料 } & $\mathrm{NH}_{4}-\mathrm{N}$ & 42.3 & 69.2 & 94.7 & 85.5 & 93.0 & 79.3 \\
\hline & $\mathrm{NO}_{3} \rightarrow \mathrm{N}$ & 57.7 & 30.8 & 5.3 & 14.5 & 7.0 & 20.7 \\
\hline
\end{tabular}

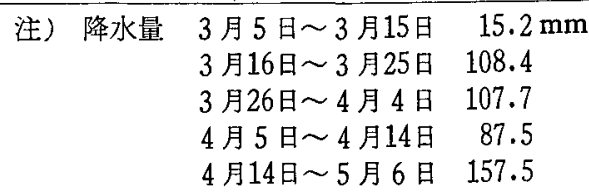

表12 茶樹細根の主要了ミノ酸

(mg/100g)

\begin{tabular}{|c|c|c|c|c|c|c|c|c|c|c|c|}
\hline 処 理 & 採取時期 & $\begin{array}{l}\text { アンモ } \\
=. ア\end{array}$ & $\begin{array}{l}\text { アルギ } \\
\stackrel{2}{=}\end{array}$ & $\begin{array}{l}\text { アスパラ } \\
\text { ギン酸 }\end{array}$ & セリン & テア & $\begin{array}{l}\text { グルタ } \\
\text { ミン酸 }\end{array}$ & その他 & 全了” & $\begin{array}{l}\text { 同左 } \\
\text { 指数 } \\
\end{array}$ & $\begin{array}{l}\text { 勍総量 } \\
\text { 比了=率 }\end{array}$ \\
\hline \multirow{2}{*}{ 㤫機質 } & 春肥直前 & 38.4 & 428.8 & 25.6 & 131.4 & 2451.6 & 30.2 & 65.4 & 3171.4 & 100 & $77.3^{\%}$ \\
\hline & 一茶摘採時 & 29.6 & 990.8 & 47.8 & 273.6 & 3287.6 & 31.2 & 134.6 & 4795.4 & 100 & 68.6 \\
\hline \multirow{2}{*}{ 㤫機 斦悬 } & 春肥直前 & 30.8 & 265.0 & 28.4 & 203.4 & 1788.2 & 38.2 & 132.4 & 2486.4 & 78.4 & $71.9^{\circ}$ \\
\hline & 一茶摘採時 & 41.2 & 518.4 & 42.6 & 245.4 & 2303.8 & 30.2 & 143.0 & 3324.6 & 69.3 & 69.3 \\
\hline \multirow{2}{*}{$\begin{array}{l}\text { 有機質 } \\
\text { 量 }\end{array}$} & 春肥直前 & 35.4 & 322.8 & 24.8 & 191.4 & 1957.0 & 30.4 & 63.2 & 2626.0 & 82.8 & 74.5 \\
\hline & 一茶摘採時 & 19.4 & 667.2 & 43.2 & 93.8 & 2266.0 & 22.8 & 103.4 & 3215.8 & 67.1 & 70.5 \\
\hline \multirow{2}{*}{$\begin{array}{l}\text { 楥 効 性 } \\
\text { 料 }\end{array}$} & 春肥直前 & 25.0 & 578.8 & 23.2 & 201.6 & 2519.8 & 29.4 & 59.0 & 3436.8 & 108.4 & 73.3 \\
\hline & 一茶摘採時 & 60.4 & 861.0 & 61.4 & 226.0 & 2976.2 & 29.4 & 125.0 & 4339.4 & 90.5 & 68.6 \\
\hline
\end{tabular}


表13茶業扢よび茶園土軖の無機成分含量

\begin{tabular}{|c|c|c|c|c|c|c|c|c|c|c|c|c|c|}
\hline 試 & 料 & 処. & $\begin{array}{r}\mathrm{T}-\mathrm{N} \\
\% \\
\end{array}$ & $\begin{array}{r}\mathrm{P}_{2} \mathrm{O}_{5} \\
\quad \% \\
\end{array}$ & $\begin{array}{l}\mathrm{K}_{2} \mathrm{O} \\
\quad \%\end{array}$ & $\begin{array}{c}\mathrm{CaO} \\
\mathrm{mg} / \\
100 \mathrm{~g}\end{array}$ & $\begin{array}{c}\mathrm{MgO} \\
\mathrm{mg} / \\
100 \mathrm{~g} \\
\end{array}$ & $\begin{array}{c}\mathrm{Zn} \\
\mathrm{ppm}\end{array}$ & $\begin{array}{c}\mathrm{Fe} \\
\mathrm{mg} / \\
100 \mathrm{~g}\end{array}$ & $\begin{array}{c}\mathrm{Cu} \\
\mathrm{ppm}\end{array}$ & $\begin{array}{l}\mathrm{Ni} \\
\mathrm{ppm}\end{array}$ & $\begin{array}{c}\mathrm{Al} \\
\mathrm{mg} / \\
100 \mathrm{~g}\end{array}$ & $\begin{array}{l}\mathrm{Mn} \\
\mathrm{mg} / \\
100 \mathrm{~g}\end{array}$ \\
\hline & & 有機質 無施用 & 5.43 & 0.44 & 1.41 & 403.6 & 166.3 & 87.5 & 39.6 & 97.8 & 20.9 & 38.6 & 116.9 \\
\hline & & " 少量 & 5.38 & 0.41 & $1: 45$ & 430.0 & 191.5 & 87.8 & 32.1 & 111.4 & 23.5 & 40.9 & 106.5 \\
\hline & & "多量 & 5.11 & 0.45 & 1.41 & 403.5 & 174.5 & 89.1 & 28.9 & 124.8 & 16.2 & 49.9 & 114.9 \\
\hline & & 緩効 性 肥 料 & 5.23 & 0.41 & 1.33 & 359.2 & 173.1 & 86.5 & 28.1 & 105.9 & 19.8 & 37.5 & 103.5 \\
\hline 茯 & 春 & 有機質無施用 & 0.15 & 0.08 & 0.02 & 153.2 & 15.0 & 81.7 & 4020 & 40.7 & 35.6 & 6610 & 27.3 \\
\hline 3 & 肥 & " ：少 量 & 0.16 & 0.08 & 0.05 & 154.8 & 12.4 & 103.0 & 4020 & 40.7 & 38.0 & 6610 & 23.2 \\
\hline 夙 & 前 & " 多 量 & 0.23 & 0.08 & 0.05 & 156.4 & 14.8 & 87.7 & 4020 & 46.2 & 39.2 & 7110 & 22.3 \\
\hline 固 & 前 & 綬効 性 肥 料 & 0.14 & 0.09 & 0.05 & 178.0 & 12.8 & 83.8 & 4020 & 43.4 & 39.2 & 7110 & 31.5 \\
\hline \pm & 番 & 有機質無施用 & 0.16 & 0.13 & 0.02 & 138.4 & 6.5 & 1.4 & 4030 & $40: 2$ & 25.1 & 6610 & 25.4 \\
\hline & 茶 & 少 量 & 0.18 & 0.12 & 0.03 & 123.6 & 7.0 & 101.8 & 3860 & 40.2 & 27.2 & 7070 & 20.0 \\
\hline 塆 & 势 & 多 量 & 0.28 & 0.12 & 0.03 & 152.0 & 10.8 & 87.7 & 4060 & 41.8 & 27.6 & 7160 & 22.7 \\
\hline & 暗 & 緩 効 性 肥 料 & 0.16 & 0.13 & 0.02 & 152.8 & 7.1 & $83: 2$ & 4060 & 41.5 & 28.9 & 7430 & 32.4 \\
\hline
\end{tabular}

とテアニン, アスパラギン酸, アルギニンの各含量が增 加したが，なかでもアルギニン含量の増加が顕著であっ た。

全アミノ酸量に占めるテアニンの比率は，一番茶摘採 時には春肥直前に比べるとやや減少したが，処理による 一定の傾向はみられなかった。

（7）茶葉打よび茶園土壤の無機成分含量

茶葉扰よび茶園土境中の無機成分含量を表 13 に示し た。

一番茶における茶葉の全空素含量は，硫安区が多かっ たが，他の成分については区間差は明らかでなかった。

土塆中の化学成分を春肥前と一番茶摘採時で比較する と, 施肥 2 か月後の一番茶摘採時では，全窒素，リン酸

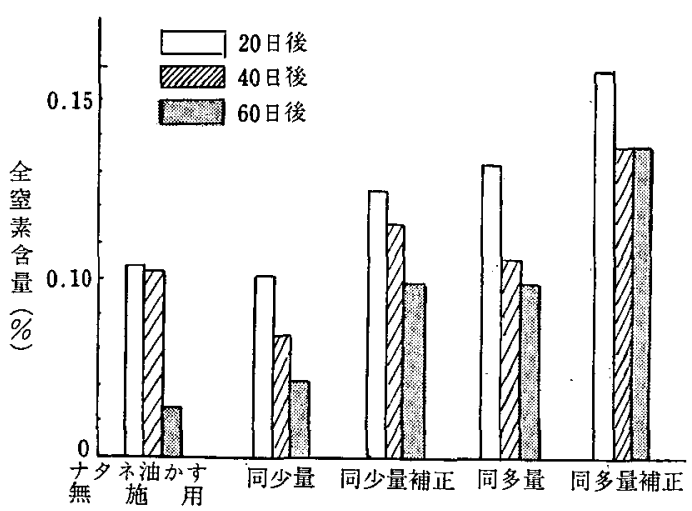

四2 土壤中:の全窒素含:量 含量の増加がみられたが，アルミニウム，铁を除 いては他の諸成分は僅かながら減少する傾向があ った。

処理区別には，いずれの時期もなたね粕施用区 の全窒甞とカリの含量が多く、リン酸含量は少な い傾向を示したが，マグネシウム、カルシウムお よびその他の然機成分の各含量には差がみられな かった。マンガン含量は紘勃性肥料区がやや多か 万.た。

\section{2 無機化率補正試験}

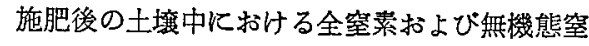
菜含量の変動を図 2，3に示した。

これらの結果についてみると，20日後では，多 量補正区が最も多く，少量補正区，多量区がこれ に次ぎ，無施用(硫安)区，少量区は少なかった。無 機態窒素含量は少量補正区を除いては，各区とも 大差なく，そのほとんどが $\mathrm{NH}_{4}-\mathrm{N} て ゙ \mathrm{NO}_{3}-\mathrm{N}$ は僅かであった。

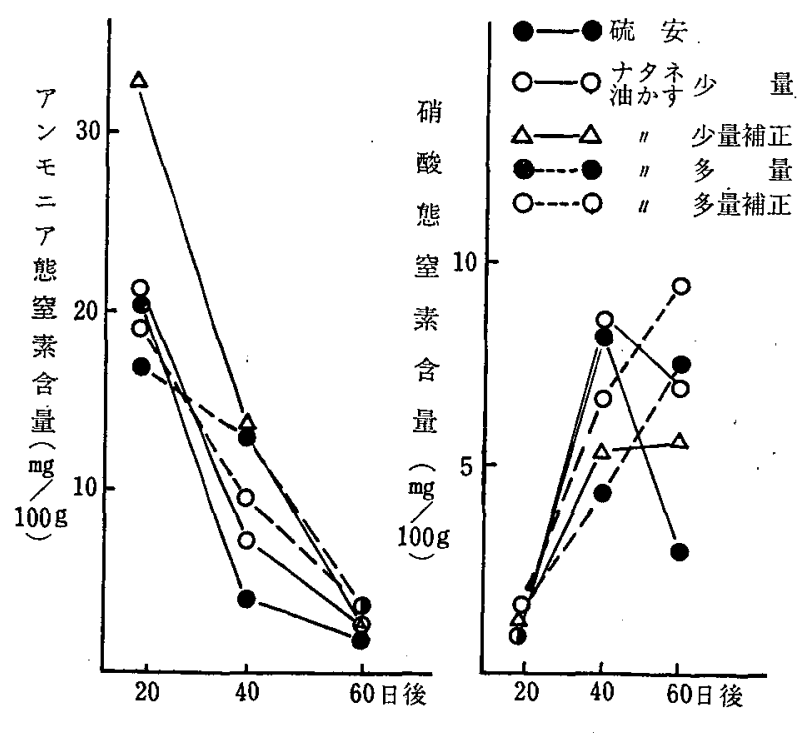

図 3・湯に打ける施肥後の無機態窒素含量 
40日後では，全窒素含量は各区とも減少した。無機態 窒素含量は硫安区が最も少なく，少量補正区す20日後に 比べて減少が大きかった。また，この時点から $\mathrm{NO}_{3}-\mathrm{N}$ の增加が顕著にみられた。

60 日後になると，区間差が明らかにみられた。すなわ ち, 硫安区之少量区に敊いて 隇少が著しかったが，多量 補正区は 40日後の場合と同様で变動がなかった。哭機態 窒素含量は，硫安区が極端に減少し，多量補正区では減 少は少ないが，これは $\mathrm{NO}_{3}-\mathrm{N}$ 含量が著しく增加した ためである。

以上の上5に，全窒菜含量岋多量補正区，多量区，少 量補正区が終始多く，こ机対して有機質の比率が少な い少量区，硫安区は20日後において，すでにやや少な く，その後の減少率も大きかった。無機態窒素含量は硫 安区の 60 日後に批いて，低下が著しく，多量補正区との 差が顕著であった。

\section{4 考 察}

\section{1 生育と収量}

有機質肥料の茶茅の生育，収量への影響比ついては， 枠摘み芽重はなたね粕が魚粕に比べ安定して良いという 成續，䒩芽の伸びは硫安，動物性肥料火比べなたね粕が 良く，百芽重も重く，出開度の推移は低い傾向にあると い5成績など促進効果といえる埌告がある。

一方, 芽重, 茅長, 芽数, 葉数とも有機㴪肥料（なた 放粕）による影㗽は認められないという報告もあり，茶 芽の生育に対する影響は明らかではない。

有機質肥料としてなた极粕を用いた本碔験では，多量 区の芽数は多くはないが芽長はよく伸びて長く，百牙重 も重かった。これに対し硫安区は, 芽は少さく, 出開度 の進みが早い傾向がみられ，鹿児島茶試の成績とよく似 た結果であった。これらのことからななね絈は茶芽の 伸びを促進し，芽重を增加させるものと考兄られる。

収量は，一，二香茶ともなた和粕区は硫安区に比べて やや少り，とくに二番茶の忹うが低収を示した。これ

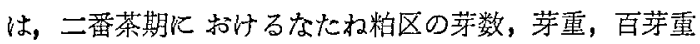
が少ないためと思われる。なたね粕区の収量が硫安区に 比べて劣る傾向は農林水産省茶試枕崎支場の報告にもみ られ，なたね粕は一，二番茶の収量は少ないが，三番茶 では硫安との差が少なくなったことから，低収の原团は 有機質肥料の肥効に関連があると推察している。本試験 に扔いても，なた柏多量区では施用後，硫安区に比べ て土境中に招ける全窒素および 無機態窒素含量の隇少が 湲やかて残存量も多いことから，収量がやや劣るのは，
なたね粕の分解速度が遅いためと考学られる。

\section{2 製茶品質および成分}

肥料の種類と製茶品啠との関係については，なたね 粕, 骨粉等の有機質肥料炕よる製茶品質の差は活とんど ないという報告もあるが，なたね粕が最も品質優秀で， 大豆粕, 硫安は外镜, 内質とも劣るとい5 報告, 硫安は なたね粕に比べて品質が劣るという報告など有機質肥料 の効果を認めたるのが多い。

本試験でも，製茶品筫は概して，なたね粕区が優れた が，外歓は年度による变動があっで区閂差は明らかでな かった。内質では水色, 香気, 味とる硫安区, 綬效性肥料 区が劣りとくに硫安区では香気が灭しかった。水色は， なたね粕区が清澄な黄金色でせん茶として優れ，硫安区 は淡くやや劣った。水色阔する研究は, 朔出晹温, 脰 出時間，眝蔵条件の差による水色の変化あるいは硬度， $\mathrm{pH}$ など使用した水の性質と水色の関係等主に製造技術 改善のためのものが多い。裁培面では，女儿茶の水色に 関係の深、黄色色素, 主にフラボノール類括よびフラボ ン類の量が茶期や被覆によって変化する。すなわち,二 番茶に比べて一番茶が多く，被覆により隇少すること， 葉緑素は玉露など被稪茶に多いことなどが報告されてい る。

しかし，本試験は色素の分析を行っていないので，成 分的な面からは明らかなことはい充ない。

肥料の種類と茶の香気に 関する報告は少ないが，なた ね粕を施用した茶は香気が良く，香気化特徽を持つ炫統 に属すると推察している報告もある。本試験でる，なた ね粕区の香気が優れたが，香気成分について分析を行っ ていないので，明らかなことはい党ないが，なたね粕が 有効化㗢いていることも推測される。

滋味は，なたね粗の両区が優れたが，5ま味に関連性 が大きいとされる整茶中の全㗧菜含量，全アミノ酸量は 硫安区の活らが多く，なた柏区では少なかった。なた ね粕区では全窒索执よび全アミノ酸の各含量が少ないに もかかわらず，官能審查の評点が優れたのは，中川が報 告しているよ5K，緑茶の味之成分の関係は，特定の成 分量の多少といら直線的な関係ではなく，それぞれの成 分が最適濃度範囲に存在する曲線的な関係にあったるの とみられる。すなわち，アミノ酸, タンニン，カフェイ ン，迶離還元糖など 各種成分の調和の重要性が推察され た。また，品質評点，とくに内質の栠れるるのは概して 全アミノ酸に占めるテアニンの比率が高い傾向にある がななた粕多量区の品質評点が優れたのはこのような 成分の調和が関与したものと思考される。一番茶のカテ $\dagger 1$ 京都府茶業研究所: 昭和 39 年度 土䖯肥料に関する試験

†2 鹿児島県茶業試験場: 昭和 51 年度 土壤肥料汇関する試験成績

$† 3$ 埼玉県茶業試験場：昭和 48 年度 土㙵肥料炕関する試験成績

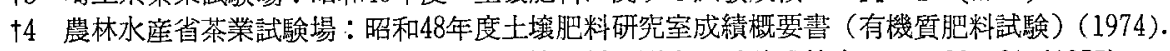

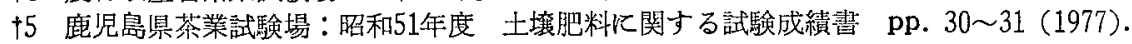

pp. 9 (1965).

pp. $17(1976)$.

pp. 14 (1974). 
キン含量は，なたね粕区，緩効性肥料区がやや多く，硫 安区が少ない傾向であったが，品質調査を行っていない 年度の結果なので品質との関係については明らかなこと はいえない。

\section{3 土壤化学性およびほ場におげる無機態窒素}

この試験では，洪皘層赤黄色土袞において，なたね粕 を年間最高 $720 \mathrm{~kg} / 10 \mathrm{a}$ 施用した。告の結果，跡地土境 への影響としては，なたね粕区において全炭素含量が増 加し塩基置換容量が増大する傾向がみられ。 $\mathrm{pH}$, 全空素 含量，置換性塩基などについては明らかな差はみられな かった。これらの変動が少ないのは，時期や年度により 異なることと，試験期䦓中，乙き草，堆肥などの有機物 や苦土石灰を施用しなかったことる原因として考えられ る。このため，なた柏のみでなく苦土石灰，有機物投 入などによる土境改良の必要性を示していると思われ る。

春肥後の土墥中の無機態空菜の 動きを調查した結果， 肥料の種類によって異なった動きがみられた。すなわ ち、なたれ粘多量区の窒䒺の 無機化はゆるやかで，無機 態堂素含量は硫安区に比べて低いが持続性がある。これ に対して硫安区は無機態窒素の供給が急速で，また減少 すはやく持続性にやや欠けることが示され，このため製 茶中の全窒素含量が，硫安区の活らがなたね粕区に比べ て多いるのと思われる。

活場沉括什るなたね粕中の窒素の無機化は気象条件や 微生物などの影響により变動すると思われるが，やはり 低いよ5である。池ヶ谷らは，なたね粕は7 日目までに 全窒菜中の $40 \%$ が $\mathrm{NH}_{4}$ 一 になり，以後は $\mathrm{NH}_{4}-\mathrm{N}$ の 生成はあまり增加せず，21 日目にはアンモ二ア化成率 42.4\%，硝酸化成率 $12 \%$ であったとい5。なたね粕中の 窒素の無機化率が低く，硝酸化成率子低い原因について は松采によると，なたね粘の分解中には酪酸，芥子油な どが生成し，酸性を呈し微生物の活動，繁殖を抑制する ためであると推測されている。

なたね粕と琉安の肥効の差を考察する場合，施肥方法 として, 根の活動期に 比較的高濃度飞窒素を供給する場 合と，一定の濃度を継続的に維持する場合とでは異なる すの思われる。石垣らは，茶樹では他の作物䎲比べて アンモニアの害作用があらわれにくいこと，また過剩の $\mathrm{NH}_{4}$ 一N を吸収した場合，これがテアニンに取り込まれ て, $\mathrm{NH}_{4}$ - $\mathrm{N}$ の解清作用を営んでいるので, むしろ, $\mathrm{NH}_{4}$-N を過剩他用した潘うが茶葉中のテアニン含量 が増加し，品質にす好影響を与えることが考党られると 報告している。この陚験においてる $\mathrm{NH}_{4}-\mathrm{N}$ の供給が 急激な硫安区の製茶中の全坴素含量, 全アミノ酸量がな たね粕区比べ多いことと相通ずるすのとみられる。

\section{4 茶樹細根のアミノ酸}

細根中の全アミノ酸量は硫安区, 綬効性肥料区に多く,
なたね粕区では少ない。また茶葉（製茶）中の全害菜含 量, 全アミノ酸量も同様になたね粕区のほ5が少ない傾 向があり，肥料の種類による窒菜供給能の相違に基うく 全窒素含量に影響されるるのと推測される。

時期别にみると，一番茶摘採時の全厂ミ/酸含量打上 びテアニン含量も春肥直前に比べて多くなった。一番茶 期では土壤から吸収された 窒素之樹体内の貯蔵性窒素の 闻方によって新芽に窒菜が集中して生長が行われている ことが認められている。本試験の結果については，春肥 施用から一番摘採焉での間に吸収された窒素を元に，根 に㧊いて生成された多量のアミノ酸の地上部への転流が 肥料の種類による差異として示された。しかし，萌芽期， 開葉期など生育過程に括ける稩根の全窒素，アミノ酸な どの動きをさらに詳しく調べる必要があると思われる。

了ミノ酸を種類別にみると，春肥直前，一番茶摘採時 には，テアニンが圧倒的に多く，アルギニン，セリンが これに次ぎこれら 3 種類で全アミノ酸の $95 \%$ 前後を占 めている。また，テアニンは茶葉，細根に多く，細根で はアルギニンが多いのが特徽であった。

\section{5 摘 要}

有機質肥料としてなたね粕，無機質肥料として硫安を 用い，その比率をかえて供試し，さらに緩効性肥料とし て CDU を加点, 茶芽の生育, 生葉収量, 慗茶品犋, 製 茶成分ならびに土墥化学性等に及活す影響を検討した。

1 茶芽の生育は，なたね粕区が硫安区に比べ儌れる 傾向がみられたが，生葉収量は芽数，芽重, 出開度の調 和のとれた硫安区がやや多く，ての他の区は僅かながら 減収となった。

2 製茶品質は，外観に処理区間の差はあまりみられ ないが，水色，香気，味の内質については，なたね粕区 が優れ，とくになたね粕多量区の審查評点が高かった。

3 製茶成分のなかで, 全窒菜含量, 全アミノ酸量は 硫安区と緩效性肥料区に多く，なた䄸多量区に少な い。热湯可溶分はなたね粕多量区に多く，タンニシ，可 溶性窒素含量の区間差は判然としなかった。アミノ酸の なかで, 最る含量の多いテアニンが全アミノ酸に占める 比率は，なたね粕多量区が高く，硫安区は低かった。

4 土境の化学性は，なたね粕施用により全炭素含量，

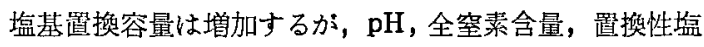
基については，変化はあまりみられなかった。

5 なたね粕多量区に扝ける土靖中の無機態空素含量 は，春肥施用20日後にかなり高くなるが，その後も無機 化はゆるやか纪続き他区に比べて長期間多く保たれた。 硫安区の無機化は，10日後に最高となり以後急速に減少 し，40〜60 日後の含量は，なたね粕多量区に比べ少なか った。緦效性肥料区の無機態窒素含量は，終始少なく無 機化がゆるやかな傾向を示した。 
6 細根中の全アミノ酸量は, 茶葉（製茶）中の全ア ミノ酸量と活に同様任, 硫安区, 緩勃性肥料区が多く, なたね粕区では少なかった。時期別には，一番茶摘採时 が春肥直前比比べて各区とも多かった。アミノ酸は，テ アニンが最も多く, 全アミノ酸量に占める比率は, 一番 茶摘採時には春肥直前に比べやや低下した。

7 製茶品質に関係の大きい䒩葉中の全窒素含量，全 アミノ酸量は硫安区に多く，なたね粕区が少ない傾向を 示したが，製茶品質とくに内質の審査評点では，硫安区 が劣り，なたね粕区が優れた。これは，茶の品質が，茶 葉中に打ける品質関与成分の量的な多少のみではなく， 各種成分の調和が強く影響するすのと考学られる。

本試験を実施するにあたり，ご指導を賜わった農林水 産省茶試池ヶ谷賢次郎博士，当場畑地土じょ5研究空高 橋和司室長，アミノ酸，カテキンなどの分析のご指導を 賜わった農林水産省茶試化学研究室長 中川致之博士活か 室員の方々，本報をとりまとめるに当たって懇切なるご 指導を晹った農林水産省茶試平拏重郎栽培部長，同土裹 肥料研究室長 石垣幸三博士飞 対し 厚く感謝の意を表す る。

\section{6 引用文 献}

1）押因幹太：農学大系 茶編, 盖賢堂, pp. 118 122 (1951).

2）田辺 貢：実験茶樹栽培及び製茶法，西ケ原刊行 会, pp. 145 146 (1934).
3) 茶試化学研究室: 農林省茶業試験場研㠰報告, No. 6, 167 172 (1970).

4) Hanes, C.S.: Biochem. J., 23, 99 (1929).

5) 中川致之，鳥井秀一：茶技研，No. 29，67〜76 (1964).

6) 久保田悦郎，中川致之：茶技研，No. $45 ， 51 \sim 57$ (1973).

7) 石垣幸三，高柳博次 : 茶技研， No. 40，53～58 (1970).

8）土壤養分測定委員会：土壤養分分析法，敨蜸堂， pp. 186 192 (1975).

9）池ヶ谷賢次郎：茶試研報，No. $10 ， 133 \sim 208$ (1974).

10）坂本 裕：農林省茶業試験場研究報告, No. 6 , $1 \sim 63$ (1970).

11）静岡県茶業会議所：新茶業全書，静岡県茶業会議 所, pp. 374 375 (1966).

12）中川致之：茶研報，No. 40, 1〜6 (1973).

13）池分谷賢次郎，平崒重郎：茶技研，No. 53，65～ 73 (1977).

14) 松木五楼：総合肥料学, 朝食書店, pp. 341 (1957).

15）石垣幸三，保科次雄：茶研報，No，45，54～62 (1977).

16）保科次雄，香西修治，本䓅吉男：茶技研，No. 56, $66 \sim 69$ (1979).

(Apr. 23, 1979) 